\title{
Implikasi Hak Recall Partai Politik Terhadap Sistem Kedaulatan Rakyat
}

\author{
Malicia Evendia
}

\section{Mahasiswa Bagian HTN Fakultas Hukum Universitas Lampung}

\begin{abstract}
Abstrak
Penelitian ini bertujuan untuk mengetahui apakah pengaturan hak recall partai politik sejalan dengan prinsip kedaulatan rakyat. Jenis penelitian ini adalah normatif, menggunakan pendekatan undang-undang (statute approach), pendekatan kasus (case approach) dan pendekatan historis (historical approach). Hasil penelitian menunjukkan bahwa pengaturan hak recall partai politik dalam peraturan perundang-undangan, tidak sejalan dengan prinsip kedaulatan rakyat, bahkan menggeser kedaulatan rakyat menjadi kedaulatan partai.
\end{abstract}

Kata Kunci : Recall, Kedaulatan Rakyat, dan Partai Politik.

Pendahuluan

Pasal 1 ayat (2) UndangUndang Dasar Negara Republik Indonesia Tahun 1945 (UUD Tahun 1945) menyatakan bahwa "Kedaulatan berada ditangan rakyat dan dilaksanakan menurut UndangUndang Dasar." Implementasi ketentuan tersebut, kedaulatan rakyat dilaksanakan melalui sistem perwakilan (representation).

Pengisian lembaga perwakilan dilaksanakan melalui pemilihan umum (pemilu). ${ }^{1}$ Dengan demikian, pemilu adalah salah satu instrumen mewujudkan kedaulatan rakyat yang bermaksud membentuk pemerintahan yang sah serta sarana mengartikulasi aspirasi dan kepentingan rakyat. $^{2}$ Rekrutmen keanggotaan lembaga perwakilan rakyat (DPR/DPRD) berbasis partai politik, sehingga tidak ada satupun anggota perwakilan rakyat yang tidak terikat pada suatu partai politik. Sebagaimana tercermin

\footnotetext{
${ }^{1}$ Lihat Pasal 22E ayat (2) UUD Tahun 1945.

${ }^{2}$ Ibnu Tricahyo, Reformasi Pemilu Menuju Pemisahan Pemilu Nasional dan Lokal, (Malang: In-Trans Publishing, 2009), hlm. 6.
}

dalam Pasal 22E ayat (3) UUD Tahun 1945 yang menyatakan bahwa "peserta pemilihan umum untuk memilih anggota Dewan Perwakilan Rakyat dan anggota Dewan Perwakilan Rakyat Daerah adalah partai politik."

Dalam Pasal 213 ayat (1) dan (2) serta Pasal 383 ayat (1) dan (2) UU MPR, DPR, DPD, dan DPRD (UU MD3) menentukan bahwa anggota DPR dan DPRD selain dipilih, dapat diberhentikan dari jabatannya (Pemberhentian Antar Waktu) yang salah satu alasannya yaitu apabila diusulkan oleh partai politiknya untuk diberhentikan sebagai anggota DPR/DPRD sesuai dengan ketentuan peraturan perundang-undangan. ${ }^{3}$

Harun

mengemukakan $\mathrm{Al}$

pemberhentian Antar Waktu atau yang biasa disebut Recall adalah hak suatu partai politik untuk menarik kembali anggota parlemen yang terpilih melalui daftar calon yang

${ }^{3}$ Lihat Pasal 383 ayat (2) huruf e UU MD3. 
diajukannya. ${ }^{4}$ Dalam hal ini makna dari kedaulatan rakyat menjadi semu karena seolah-olah ada Coup dari pimpinan partai yang merebut hak rakyat untuk melakukan recall menjadi hak partai. Muhammad Hatta menyatakan bahwa hak recall partai politik yang tidak dapat diganggu gugat itu hanya dikenal di negara-negara komunis, dengan pandangan bahwa partai adalah segala-galanya dan seolah-olah sebagai pihak yang berdaulat. $^{5}$ Setelah rakyat memilih orang tersebut sebagai wakil mereka di parlemen, maka partai politik tidak sepatutnya bertindak sewenangwenang me-recall wakil rakyat tersebut.

Dari hal diatas, muncul sebuah permasalahan bahwasannya kedaulatan partai politik mampu menggeser kedaulatan rakyat. Berdasarkan permasalahan tersebut, sebuah pertanyaan mendasar yang memerlukan penelitian yaitu apakah pengaturan hak recall partai politik sejalan dengan prinsip kedaulatan rakyat?

\section{Pengaturan dan Implementasi Hak Recall Partai Politik}

Black's Law Dictionary mendefinisi recall yaitu Removal of a public official from office by

\footnotetext{
${ }^{4}$ Risalah Sidang Mahkamah Konstitusi Perkara No. 008/PUUIV/2006 tentang Pengujian Undang-Undang Nomor 22 Tahun 2003 Tentang Susunan Dan Kedudukan MPR, DPR, DPD, dan DPRD Serta UndangUndang Nomor 31 Tahun 2002 Tentang Partai Politik Terhadap UUD Tahun 1945.

${ }^{5}$ Yusril Ihza Mahendra, Dinamika Tatanegara Indonesia: Kompilasi Aktual Masalah Konstitusi, DPR dan Sistem Kepartaian, (Jakarta: Gema Insani Press, 1996), hlm. 171
}

popular vote. ${ }^{6}$ Sementara, dalam kamus politik karangan BN Marbun, recall diartikan sebagai suatu proses penarikan kembali atau penggantian anggota DPR oleh induk organisasinya, yaitu Partai Politik. ${ }^{7}$

Pengaturan pemberhentian anggota DPR dalam konteks sejarah di Indonesia telah mengalami dinamika. Pengaturan recall pada zaman orde baru secara tegas dikonstatir dalam Pasal 4 UndangUndang Nomor 16 Tahun 1969 tentang Susunan dan Kedudukan Majelis Permusyawaratan Rakyat, Dewan Perwakilan Rakyat, dan Dewan Perwakilan Rakyat Daerah. ${ }^{8}$ Praktek recall zaman orde baru jarang terjadi. Hal itu karena situasi dan kondisi perpolitikan dalam praktek kenegaraan sangat homogen dibawah satu komando sang presiden, yakni Soeharto. Recall pada saat itu digunakan sebagai senjata untuk membungkam politisi yang tidak mengikuti irama alunan dari sang presiden. Bukti sejarah penggunaan hak recall pada masa ini yang sangat kontroversial yaitu pemberhentian anggota DPR yang bernama Sri Bintang Pamungkas,

\footnotetext{
${ }^{6}$ Bryan A.Garner, Black's Law Dictionary: Seventh Edition, (United Staties of America: West Group ST. Paul Minn, 2000), hlm. 1019.

${ }^{7}$ www.hukumonline.com. Mempertanyakan Hegemoni Recall Anggota DPRD Di Tangan Partai Politik, 22 Januari 2007, Diakses Tanggal 14 Januari 2013 Pukul 21.18

${ }^{8}$ LNRI Tahun 1969 Nomor 59, TLNRI Nomor 2915

${ }^{9}$ http://www.ipu.org/hr-e/162/ids10.htm, selain itu Sri bintang Pamungkas masuk penjara/ jeruji besi dikarenakan mengkritik Soeharto, kemudian dibebaskan oleh B.J.Habibie pada masa pemerintahannya, lihat http://id.wikipedia.org/wiki/Bacharuddin_Ju suf_Habibie.
} 
yang berasal dari Partai Persatuan Pembangunan.

Alasan pemberhentian karena menyampaikan kritik-kritik kepada pemerintah dan menolak pertanggungjawaban presiden.

Kondisi berubah pada tahun 1998 ketika Soeharto mengundurkan diri. ${ }^{10}$ Tuntutan untuk menghapus lembaga recall (pemberhentian ditengah jalan) terhadap anggota DPR/DPRD sudah banyak dikemukakan pada masa Orde Baru. Adanya sistem recall menyebabkan banyak wakil rakyat menjadi tidak kritis, bahkan takut untuk menyuarakan aspirasi masyarakat. Pada era reformasi, recall berhasil ditiadakan, recall kecuali dengan alasan yang tak bisa dihindari yakni meninggal, mengundurkan diri, atau dijatuhi hukuman pidana dengan kualifikasi tertentu. $^{11}$

Pada masa sesudah Perubahan UUD 1945, penggantian anggota DPR tercantum kembali dalam Pasal 85 Undang-Undang Nomor 22 Tahun 2003 tentang Susunan dan Kedudukan MPR, DPR, DPD dan DPRD. ${ }^{12}$ Bukti sejarah anggota DPR yang di recall oleh partai politik melalui pengaturan ini yaitu Djoko Edhi Soetjipto Abdurahman, yang berasal dari Partai Amanat Nasional. Alasan pemberhentiannya yaitu dikarenakan Djoko Edhi Soetjipto

\footnotetext{
${ }^{10}$ Yulius P. Hermawan dalam Bob Sugeng dan Christoph Schuck, Demokrasi di Indonesia: Teori dan Praktik, (Yogyakarta: Graha Ilmu, 2010), hlm. 99.

${ }^{11}$ Moh. Mahfud MD, Perdebatan Hukum Tata Negara (pasca amandemen konstitusi), (Jakarta: PT Raja Grafindo Persada, 2010), hlm. 165.

${ }^{12}$ LNRI Tahun 2003 Nomor 92, TLNRI Nomor 4310.
}

Abdurahman ikut studi banding RUU perjudian ke Mesir. ${ }^{13}$

Saat ini pengaturan recall diatur dalam Pasal 213 ayat (1) dan (2) UU MD3, dan dipertegas dalam Pasal 16 ayat (1) UU Partai Politik. Hal ini memberikan kewenangan yang luar biasa besar kepada partai politik untuk memberhentikan atau me-recall anggotanya yang duduk sebagai anggota DPR yang bisa hanya didasarkan atas suka atau tidak suka atau bertentangan dengan kebijakan partai. Bukti sejarah anggota DPR yang diberhentikan oleh pengaturan ini yaitu Lily Wahid dan Effendi Choiri, yang berasal dari Partai Kebangkitan Bangsa. Alasan pemberhentiannya yaitu mereka berbeda pendapat dari kebijakan partai yang menaunginya, dalam keputusan terkait panitia khusus hak angket Bank Century, serta di usulan hak angket mafia pajak. ${ }^{14}$

Berdasarkan analisis dinamika pengaturan dan implementasi hak recall partai politik diatas, penulis menyimpulkan bahwa awal mula adanya hak recall partai politik adalah dijadikan alat bagi partai politik dalam mengendalikan anggotanya yang ada di parlemen. Hal ini merupakan upaya partai politik dalam mempertahankan kekuasaannya di parlemen. Recall dijadikan pranata untuk membungkam anggota dewan yang kritis dan tidak sesuai dengan kebijakan partai politik. Sehingga pada masa awal reformasi, ketika semangat perubahan untuk

\footnotetext{
${ }^{13}$ Lihat

http://www.rakyatmerdeka.co.id/news/2006/ 11/28/23278/Djoko-Edhi-Beberkan- diakses pada tanggal 15 Desember 2012 pukul 13.08 .

${ }^{14}$ http://www.abdulghoffar.com/2012/01/ses at-recall-partai.html diakses pada tanggal 27 November 2012 pukul 09.07
} 
mengembalikan kedaulatan ke tangan rakyat, recall ditiadakan. Dengan begitu, recall partai politik saat ini tidak selaras dengan semangat demokrasi, karena menempatkan kewenangan partai politik lebih besar daripada rakyat melalui hak recall partai politik.

\section{Pemilu sebagai Instrumen Kedaulatan Rakyat}

Kedaulatan merupakan hak kekuasaan mutlak, tertinggi, tak terbatas, tak terbendung dan tanpa terkecuali. ${ }^{15}$ Sistem pemerintahan yang menganut teori kedaulatan rakyat, yakni kekuasaan pemerintah dipegang dan dijalankan oleh lembaga-lembaga negara yang terbentuk dari rakyat, oleh rakyat dan untuk rakyat (demokrasi). Perwujudan kedaulatan rakyat dilaksanakan melalui Pemilu secara langsung sebagai sarana bagi rakyat untuk memilih wakilnya. Sistem yang dianut akan berpengaruh, baik berkenaan sistem pemilihan umum maupun sistem kepartaian, sangat mempengaruhi esensi keterwakilan rakyat. $^{16}$

Sistem Pemilu di Indonesia telah mengalami perubahan dari waktu ke waktu. Pemilu 1999 mengadopsi sistem perwakilan proporsional dengan daftar tertutup. Melalui sistem ini, partai-partai politik membuat daftar calon anggota DPR dan DPRD, setiap kandidat ditetapkan berdasarkan perangkingan dan daerah pemilihan kabupaten/kota atau kecamatan dimana mereka akan

\footnotetext{
${ }^{15}$ Padmo Wahjono, Ilmu Negara, (Jakarta: Indo Hill Co, 1961), hlm. 153.

${ }^{16}$ Jimly Asshiddiqie, Format Kelembagaan Negara dan Pergeseran Kekuasaan dalam UUD 1945, (Yogyakarta: FH UII Press, 2005), hlm.44.
}

wakili. Para pemilih memilih partaipartai politik dengan mencoblos satu gambar partai di kertas suara. Komite pemilihan kemudian akan menentukan siapakah kandidat yang terpilih sesuai dengan rangking mereka dalam daftar partai. Sehingga sistem daftar tertutup dari perwakilan proporsional memberikan kewenangan kepada partai untuk menentukan anggota parlemen dan dewan yang terpilih.

Pemilu 2004 mengadopsi sistem daftar terbuka untuk memilih anggota-anggota DPR, DPRD Provinsi dan DPRD Kabupaten/kota. Melalui sistem ini, para pemilih memilih partai dan sekaligus kandidat tertentu. Melalui mekanisme ini partai politik mengajukan para calon dalam daftar dan masyarakat yang memilih langsung calon. Calon yang memenuhi Bilangan Pembagi Pemilih (BPP) langsung menjadi wakil rakyat dari daerahnya. Namun sayangnya hanya calon yang peroleh suara mencapai BPP yang dapat dinyatakan terpilih. Hanya ada dua kandidat yang dapat memperoleh suara yang mencukupi untuk mendapat kursi dalam DPR pada pemilu 2004. Mereka adalah Hidayat Nur Wahid dan Saleh Djasit. Oleh karenanya, penetapan berdasarkan nomor urut tersebut, membuat kesenjangan wakil rakyat, konstituen dan parpol masih terjadi, karena peran partai yang masih dominan dalam menentukan calon yang menjadi wakil di parlemen berdasarkan nomor urut yang ditentukan partai.

Awalnya sistem pemilu pada tahun 2009 menggunakan sistem proporsional dengan daftar terbuka seperti pemilu pada tahun 2004. Kemudian, melalui putusan 
Mahkamah Konstitusi Nomor 2224/PUU-VI/2008, telah mengubah sistem pemilu menjadi sistem proporsional terbuka dengan penerapan suara terbanyak yang menempatkan kedaulatan berada di tangan rakyat. Berdasarkan Putusan MK tersebut, penempatan nomor urut dinilai sebagai bentuk oligarki partai politik yang menegasikan kehendak rakyat dalam menentukan wakilnya. Selanjutnya, sistem pemilu yang akan diterapkan dalam pemilu Tahun 2014 mendatang juga masih sama seperti pemilu Tahun 2009 yaitu proporsional terbuka dengan penerapan suara terbanyak. Hal ini dipertegas dalam Pasal 5 ayat (1) dan Pasal 215 Undang-Undang Nomor 8 Tahun 2012 tentang Pemilihan Umum Anggota DPR, DPD, dan DPRD.

Pemilihan umum dimaksud diselenggarakan dengan menjamin prinsip keterwakilan, yang artinya setiap orang warga negara Indonesia terjamin memiliki wakil yang duduk di lembaga perwakilan yang akan menyuarakan aspirasi rakyat di setiap tingkatan pemerintahan, dari pusat hingga ke daerah.Rakyat sebagai subjek utama dalam prinsip kedaulatan rakyat, seharusnya tidak hanya ditempatkan sebagai objek oleh peserta Pemilu dalam mencapai kemenangan semata.

Pemberhentian anggota dewan melalui mekanisme recall oleh partai politiknya, merupakan hal yang akan menusuk rasa keadilan dan melanggar kedaulatan rakyat dalam artinya yang substantif, karena tidak ada rasa dan logika yang dapat membenarkan bahwa keadilan dan kehendak rakyat sebagai pemegang kedaulatan rakyat dapat dilanggar dengan cara recall, karena kemenangan seseorang calon untuk terpilih tidak lagi digantungkan kepada partai politik peserta Pemilu, tetapi sampai sejauh mana besarnya dukungan suara rakyat yang diberikan kepada calon tersebut.

Partai politik seharusnya tidak berwenang untuk memberhentikan anggotanya yang berada di DPR, hal ini mengingat anggota DPR terpilih adalah representasi dari suara mayoritas rakyat yang memilihnya. Besarnya suara pilihan rakyat menunjukkan tingginya legitimasi ${ }^{17}$ politik yang diperoleh oleh para calon anggota legislatif, sebaliknya rendahnya perolehan suara juga menunjukkan rendahnya legitimasi politik calon anggota legislatif. ${ }^{18}$ Dalam sistem demokrasi modern, legalitas dan legitimasi pemerintahan merupakan faktor yang sangat penting. ${ }^{19}$

Dari penjabaran dan uraian diatas, penulis menarik kesimpulan bahwa melalui sistem pemilu tertentu akan mencerminkan perwujudan kedaulatan rakyat. Sistem pemilu

\footnotetext{
${ }^{17}$ Berdasarkan pengertian legitimasi dapat dibedakan pengertian kekuasaan, kewenangan, dan legitimasi. Apabila kekuasaan diartikan sebagai kemampuan untuk menggunakan sumber-sumber yang mempengaruhi proses politik, sedangkan kewenanangan merupakan hak moral untuk menggunakan sumber-sumber yang membuat dan melaksanakan keputusan politik. Adapun Legitimasi merupakan penerimaan dan pengakuan masyarakat terhadap hak moral tersebut. Dikutip dari Ramlan Surbakti, Memahami Ilmu Politik, (Jakarta: PT Grasindo, 2000), hlm.118

${ }^{18}$ Lihat Putusan Mahkamah Konstitusi No.22-24/PUU-VI/2008 tentang pengujian Undang-Undang Nomor 10 Tahun 2008 tentang Pemilihan Umum terhadap UUD 1945

${ }^{19}$ Jimly Assiddiqie, Partai Politik dan Pemilihan Umum sebagai Instrumen Demokrasi, dalam Jurnal Konstitusi Volume 3 Nomor 4 Desember 2006, (Jakarta: Mahkamah Konstitusi RI, 2006), hlm.13
} 
dengan suara terbanyak berarti menempatkan rakyat sebagai pemegang kedaulatan, bukan lagi dominasi partai politik dalam penempatan wakil rakyat melalui nomor urut terkecil. Namun, dengan adanya pengaturan hak recall partai politik menjadikan partai politik lebih dominan terhadap pemberhentian wakil rakyat tersebut. Seharusnya, ketika rakyat sebagai pemegang kedaulatan berhak memilihnya, maka semestinya pemilih juga punya hak untuk memberhentikannya.

\section{Pergeseran Kedaulatan Rakyat}

Mac Iver mengungkapkan bahwa partai politik adalah suatu kumpulan terorganisasi untuk menyokong suatu prinsip atau kebijaksanaan (policy) yang oleh perkumpulan itu diusahakan dengan cara-cara sesuai dengan konstitusi atau undang-undang agar menjadi penentu cara melakukan pemerintahan. $^{20}$ Seorang wakil rakyat dalam pencalonannya adalah melalui partai politik dan harus menjadi partai politik tersebut, maka hubungan hukum pertama kali yang dimiliki oleh wakil rakyat adalah dengan partai yang bersangkutan. Selanjutnya dengan terpilihnya dia sebagai wakil rakyat, berarti rakyat telah memberikan amanat kepadanya untuk memperjuangkan aspirasi menjadi kebijakan publik. Hal ini dilatarbelakangi pada saat pelaksanaan pemilihan umum, yang menentukan jadi tidaknya seseorang sebagai wakil rakyat adalah bergantung kepada pilihan rakyat. Kondisi ini yang menimbulkan

\footnotetext{
${ }^{20}$ Miriam Budiarjo, Dasar-dasar Ilmu Politik, (Jakarta: PT Gramedia Pustaka Utama, 2007), Hlm.17
}

hubungan hukum antara wakil rakyat dan rakyat pemilihnya (konstituen). ${ }^{21}$ Hubungan hukum yang demikian melahirkan hak dan kewajiban yang dilindungi oleh konstitusi dan hukum, dalam rangka memberi jaminan bagi yang bersangkutan untuk menjalankan peran yang dipercayakan padanya, baik oleh partai maupun oleh rakyat pemilih. Sistem pemilihan dan partai politik yang meletakkan suatu hubungan hukum antara partai politik dengan anggotanya yang didudukkan dalam DPR pada rezim hukum pemilu, tidak dapat lagi secara mutlak mengesampingkan satu hubungan hukum antara anggota DPR dengan rakyat pemilih dan negara melalui lembaga negara DPR yang tunduk pada hukum publik (konstitusi).

Hubungan hukum yang bersifat publik demikian, memang diakui harus juga memperhitungkan hubungan hukum yang ada antara partai politik dengan anggota DPR yang dicalonkan Partai, akan tetapi hubungan hukum anggota dengan partainya, adalah dalam semangat dan diatur dalam hukum yang bersifat keperdataan (privaatrechtelijk). ${ }^{22}$ Recalling yang dilakukan partai politik terhadap anggotanya yang duduk di DPR, baik karena alasan-alasan disiplin partai dan alasan pelanggaran AD/ART, di samping diatur oleh hukum privat AD/ART partai juga harus tunduk pada hukum publik. Oleh karenanya recall partai politik sesungguhnya telah membiarkan hukum yang bersifat privat (privaatrechtelijk)

\footnotetext{
${ }^{21}$ Jimly Assiddiqie, Partai Politik dan Pemilihan Umum... Op.Cit.

${ }^{22}$ Jimly Assiddiqie, dalam Putusan Mahkamah Konstitusi No. 008/PUUIV/2006.. Op.Cit.
} 
mengesampingkan hukum publik dalam masalah konstitusional hubungan antara wakil rakyat dengan rakyat pemilih dan dengan lembaga negara yang memperoleh kewenangannya dari UUD $1945 .^{23}$ Seperti yang diketahui, berlakunya suatu konstitusi sebagai hukum dasar yang mengikat, didasarkan atas kekuasaan tertinggi atau prinsip kedaulatan yang dianut dalam suatu negara. Indonesia yang menganut asas kedaulatan rakyat, sudah tentu sumber legitimasi konstitusi adalah rakyat. $^{24}$

Mekanisme recall diluar rakyat sewajibnya dihindari karena akan menimbulkan oligarki kepartaian. ${ }^{25}$ Seringkali parpol membuat penafsiran sendiri terhadap kepentingan-kepentingan

masyarakat. Sehingga partai hanya dipahami sebagai organisasi yang hanya berorientasi kekuasaan tanpa perduli dengan kepentingan rakyat. ${ }^{26}$ Seperti kata Lord Acton yang terkenal dan sering dikutip oleh banyak penulis, 'power tends to corrupt and absolute power corrupts absolutely' (kekuasaan cenderung untuk menjadi sewenang-wenang, dan dalam kekuasaan yang bersifat mutlak, kesewenang-wenangannya juga cenderung mutlak). Inilah hukum besi kekuasaan yang jika tidak dikendalikan dan dibatasi menurut konstitusional, dapat

${ }^{23}$ Ibid.

${ }^{24}$ Jimly Assiddiqie, Pengantar Ilmu Hukum Tata Negara Jilid 1, (Jakarta: Sekretariat Jenderal dan Kepaniteraan Mk RI, 2006), hlm. 68.

${ }^{25}$ Denny Indrayana, dalam Putusan Mahkamah Konstitusi No. 008/PUUIV/2006.. Op.Cit.

${ }^{26}$ Sebastian Salang, Parlemen: Antara Kepentingan Politik vs Aspirasi Rakyat, dalam Jurnal Konstitusi..., Op.Cit., hlm. 115 menjadi malapetaka. ${ }^{27}$ Sehingga kewenangan partai politik untuk merecall anggota nya yang ada di parlemen, adalah tidak sesuai dengan prinsip kedaulatan rakyat yang menempatkan rakyat sebagai pemegang kedaulatan tertinggi.

$$
\text { George III juga }
$$

mengemukakan bahwa "Partai politik adalah suatu kumpulan orangorang yang dipersatukan, untuk meningkatkan kepentingankepentingan nasional dengan usahausaha mereka bersama, berdasar atas prinsip tertentu yang disetujui oleh mereka bersama." Karena itu George III berpendapat, bahwa perkumpulan apapun yang mempunyai tujuan politik didalam batas-batas negara, adalah suatu fraksi yang hanya mengejar keuntungan-keuntungan golongan yang tidak patriotik. ${ }^{28}$

Robert Michels juga secara khusus menolak praduga mengenai keterwakilan oleh pemimpin (representatif leadhership), karena kebanyakan kebijaksanaan organisasi massa bukan mencerminkan kemauan dan kepentingan massa, tetapi mencerminkan kemauan dan kepentingan pemimpin. ${ }^{29}$ Organisasi dan termasuk juga organisasi partai politik kadang-kadang bertindak dengan lantang untuk dan atas nama kepentingan rakyat, tetapi dalam kenyataannya di lapangan justru berjuang untuk kepentingan

\footnotetext{
${ }^{27}$ Jimly Assiddiqie, Format kelembagaan.. Op.Cit., hlm. 37

${ }^{28}$ Soewarno Hadiatmodjo, Teori-teori Politik; Sejarah Pertumbuhan dan Perkembangannya, (Jakarta: Binacipta, 1981). hlm. 255.

${ }^{29}$ Seymour Martin Lipset, Pengantar untuk edisi bahasa Inggris, dalam Robert Michels, Partai Politik Kecenderungan Oligharki dalam Birokrasi, (Jakarata: Rajawali, 1984). hlm. Xxvii.
} 
pengurusnya sendiri. ${ }^{30}$ Hal ini yang dikemukakan oleh Robert Michels sebagai suatu hukum besi yang berlaku dalam organisasi bahwa "Organisasilah yang melahirkan dominasi si terpilih atas para pemilihnya, antara si mandataris dengan si pemberi mandat dan antara si penerima kekuasaan dengan sang pemberi. Siapa saja yang berbicara tentang organisasi, maka sebenarnya ia berbicara tentang oligarki." Hal yang senada juga diungkapkan bahwa, sekali partai politik terbentuk oleh para pendukungnya, maka secara perlahan ia akan jatuh ketangan segelintir orang (oligarki) dan cenderung pada apa yang disebut hukum besi oligarki. ${ }^{31}$ Dikaitkan dengan hak recall partai politik, hal ini tergambar bahwa partai politik menjadikan recall sebagai alat untuk menguasai anggota dewan agar anggota dewan tersebut tunduk terhadap kebijakan yang dibuat partai politik. Sehingga secara tidak langsung, anggota dewan yang ada di parlemen tersebut memperjuangkan kepentingan partai politik yang menaunginya dan hal ini yang menimbulkan bahwa anggota DPR bukan lagi menjadi representatif rakyat, namun representatif sekelompok orang dalam tubuh Partai Politik.

Hoogerwerf mengemukakan ada dua model berkenaan dengan norma-norma yang mengatur kelompok mana yang harus diwakili oleh anggota DPR, yaitu (i) model

\footnotetext{
${ }^{30}$ Jimly Assiddiqie, Kemerdekaan Berserikat Pembubaran Partai Politik dan Mahkamah Konstitusi, (Jakarta: Konstitusi Press, 2006), hlm. 68

${ }^{31}$ Armen Yasir, Disharmonisasi Hubungan Kepala Daerah dengan Wakil Kepala Daerah, dalam Jurnal Penelitian Hukum Justisia, (Lampung: Penerbit Universitas Lampung, 2007).
}

kesatuan yang memandang anggota DPR sebagai wakil dari seluruh rakyat dan (ii) model diversifikasi yang memandang anggota DPR sebagai wakil-wakil dari kelompok teritorial, sosial, atau politik tertentu (daerah pemukiman, kelompok kepentingan, parpol). ${ }^{32}$ Penggunaan hak recall oleh partai politik terhadap anggota-anggotanya di parlemen, cenderung menjadikan partai politik yang bersangkutan dominan terhadap anggota-anggota partainya itu, sehingga anggotaanggota dewan lebih mementingkan kepentingan partainya ketimbang membawakan aspirasi rakyat banyak (konstituent). Denny Indrayana mengemukakan bahwa jika yang melakukan recall adalah partai, maka dibangun loyalitas kepada partai dan bukan kepada rakyat. ${ }^{33}$ Arbi sanit juga mengungkapkan bahwa dilihat dari perspektif ilmu politik dan pemerintahan menunjukkan irrelevansi hak recall dengan proses demokrasi yang dilangsungkan secara reformatif. ${ }^{34}$

Berdasarkan pandangan diatas, penulis berpendapat bahwa pelaksanaan recall oleh partai politik akan menggeser sistem kedaulatan rakyat menjadi kedaulatan partai politik. Terlihat bahwa rakyat hanya dilibatkan dalam pengambilan suara ketika Pemilu berlangsung, namun setelah calon anggota dewan tersebut terpilih, yang berhak me-recall nya adalah partai politik.

\section{Simpulan}

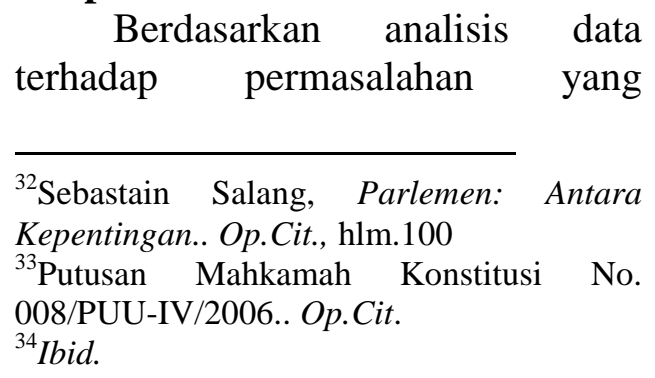

\footnotetext{
${ }^{32}$ Sebastain Salang, Parlemen: Antara Kepentingan.. Op.Cit., hlm.100

${ }^{33}$ Putusan Mahkamah Konstitusi No. 008/PUU-IV/2006.. Op.Cit.
} 
diajukan dalam penelitian ini, dapat ditarik kesimpulan bahwa pengaturan hak recall partai politik tidak sejalan dengan prinsip kedaulatan rakyat, bahkan menggeser kedaulatan rakyat menjadi kedaulatan partai politik.

Pengaturan recall partai politik dalam peraturan perundangundangan sebaiknya dihapuskan, hal ini untuk menghilangkan dasar kewenangan partai politik dalam mengendalikan anggotanya yang ada di parlemen, sehingga ketika hak recall partai politik tersebut dihapuskan maka tidak ada lagi "hantu" recall yang membuat wakil rakyat lebih tunduk terhadap partai politik dibandingkan dengan rakyat, sebagai pemilik kedaulatan. Disamping itu, perlu dibuatnya regulasi terkait mekanisme recall dengan memberikan ruang bagi konstituen sebagai pemegang kedaulatan.

\section{Daftar Pustaka}

Asshiddiqie, Jimly, Format Kelembagaan Negara dan Pergeseran Kekuasaan dalam UUD 1945, (Yogyakarta: FH UII Press, 2005).

Kemerdekaan

Berserikat Pembubaran Partai Politik dan Mahkamah Konstitusi, (Jakarta: Konstitusi Press, 2006).

Hukum Tata Negara Jilid 1 (Jakarta: Sekretariat Jenderal dan Kepaniteraan Mk RI, 2006).

Budiarjo, Miriam, Dasar-dasar Ilmu Politik, (Jakarta: PT Gramedia Pustaka Utama, 2007).

Hadiatmodjo, Soewarno, Teori-teori Politik; Sejarah Pertumbuhan dan Perkembangannya, (Jakarta: Binacipta, 1981).
Hermawan, Yulius P. dalam Bob Sugeng dan Christoph Schuck, Demokrasi di Indonesia: teori dan praktik, (Yogyakarta: Graha Ilmu, 2010).

Mahendra, Yusril Ihza, Dinamika Tatanegara Indonesia: Kompilasi Aktual Masalah Konstitusi, DPR dan Sistem Kepartaian, (Jakarta: Gema Insani Press, 1996).

Mahfud MD, Moh., Perdebatan Hukum Tata Negara (pasca amandemen konstitusi), (Jakarta: PT Raja Grafindo Persada, 2010), hlm. 165

Surbakti, Ramlan, Memahami Ilmu Politik, (Jakarta: PT Grasindo, 2000).

Tricahyo, Ibnu, Reformasi Pemilu Menuju Pemisahan Pemilu Nasional dan Lokal, (Malang: In-Trans Publishing, 2009).

Wahjono, Padmo, Ilmu Negara, (Jakarta: Indo Hill Co, 1961).

Asshiddiqie, Jimly, Partai Politik dan Pemilihan Umum sebagai Instrumen Demokrasi, dalam Jurnal Konstitusi Volume 3 Nomor 4 Desember 2006, (Jakarta: Mahkamah Konstitusi RI, 2006).

Salang, Sebastian, Parlemen: Antara Kepentingan Politik vs Aspirasi Rakyat, dalam Jurnal Konstitusi Volume 3 Nomor 4 Desember 2006, (Jakarta: Mahkamah Konstitusi RI, 2006).

A.Garner, Bryan, Black's Law Dictionary: Seventh Edition, (United Staties of America: West Group ST. Paul Minn, 2000). 